\title{
Catalytic Enantioselective Approaches to the oxa-Pictet-Spengler Cyclization and Other 3,6-Dihydropyran-Forming Reactions
}

\author{
Zhengbo Zhu ${ }^{\mathrm{a}}$ \\ Alafate Adilia \\ Chenfei Zhao ${ }^{b}$ (i) \\ Daniel Seidel*a (D) \\ a Center for Heterocyclic Compounds, Department of Chemis- \\ try, University of Florida, Gainesville, Florida 32611, USA \\ seidel@chem.ufl.edu \\ b Department of Chemistry, University of California-Berkeley; \\ Materials Sciences Division, Lawrence Berkeley National Labo- \\ ratory; Kavli Energy NanoSciences Institute at Berkeley; Berke- \\ ley Global Science Institute, Berkeley, California 94720, USA
}
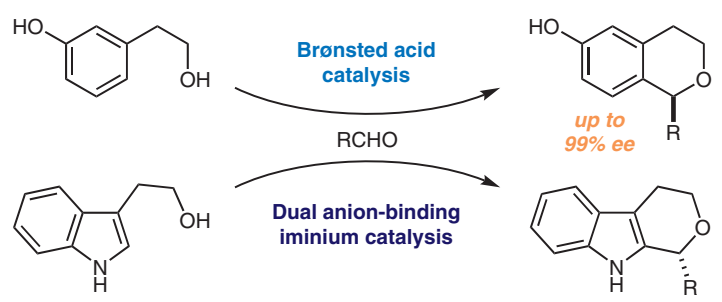

up to $95 \%$ ee
Received: 24.08.2019

Accepted after revision: 04.09.2019

Published online: 25.09 .2019

DOI: 10.1055/s-0039-1690686; Art ID: so-2019-d0023-r

License terms: $c(0) \$$

(c) 2019. The Author(s). This is an open access article published by Thieme under the terms of the Creative Commons Attribution-NonDerivative-NonCommercial-License, permitting copying and reproduction so long as the original work is given appropriate credit. Contents may not be used for commercial purposes or adapted, remixed, transformed or built upon. (https://creativecommons.org/licenses/by-nc-nd/4.0/)

Abstract This Short Review provides an analysis of the state-of-the-art in catalytic enantioselective oxa-Pictet-Spengler cyclizations. Also discussed are other catalytic reactions providing access to enantioenriched isochromans and tetrahydropyrano[3,4-b]indoles. Context is provided and remaining challenges are highlighted.

Key words oxa-Pictet-Spengler cyclization, isochromans, tetrahydropyrano[3,4-b]indoles, oxocarbenium ions, asymmetric catalysis, ion pairing

Among compounds containing a 3,6-dihydropyran core, isochromans and tetrahydropyrano[3,4-b]indoles have captured particular interest in the synthetic and medicinal chemistry communities. A small selection of compounds containing these core frameworks is shown in Figure 1. The isochroman heterocycle is a ubiquitous component of natural products often possessing intriguing bioactivities, such as ilexisochromane, ${ }^{1}$ penicisochroman $\mathrm{B},{ }^{2}$ and blapsin $\mathrm{B} .{ }^{3}$ Synthetic isochromans include the antiapoptotic agent ISO$09^{4}$ and the $5-\mathrm{HT}_{1 \mathrm{D}}$ agonist PNU-109291. ${ }^{5}$ Examples of bioactive tetrahydropyrano[3,4-b]indoles are the anti-inflammatory agent etodolac, ${ }^{6}$ the potent analgesic agent pemedolac, ${ }^{7}$ and the non-nucleoside inhibitor of hepatitis C virus HCV-371. ${ }^{8}$ The perhaps most desirable way to access isochromans and tetrahydropyrano[3,4-b]indoles in a stereocontrolled fashion is by means of the oxa-PictetSpengler cyclization; a process in which an oxocarbenium ion intermediate undergoes ring-closure onto a pendent aryl substituent. ${ }^{9}$ In this Short Review, we provide examples of asymmetric oxa-Pictet-Spengler cyclizations that are under substrate control, discuss all known catalytic enantioselective variants of the oxa-Pictet-Spengler cyclization, ${ }^{10}$ and provide an overview of other catalytic enantioselective reactions that lead to isochromans and tetrahydropyrano[3,4-b]indoles. In addition, we outline remaining challenges in this area.<smiles>CC(=O)C=C(C=O)C(CC(C)=O)CC1OCCc2cc(O)c(O)cc21</smiles><smiles>CO[C@H]1OC(C)Cc2ccc3c(c21)O[C@H](C(F)(F)F)C3=O</smiles><smiles>CCCOCC1Cc2cc3c(cc2C(c2ccccc2)O1)OCO3</smiles>
ISO-09

ilexisochromane<smiles>Oc1ccc(C2OCCc3cc(O)c(O)cc32)cc1O</smiles><smiles>COc1ccc(N2CCN(CCC3OCCc4cc(C(=O)NO[Na])ccc43)CC2)cc1</smiles>

PNU-109291

blapsin B<smiles>CCc1cccc2c3c([nH]c12)C(CC(=O)O)OCC3</smiles><smiles>CCC1(CC(=O)O)OCC(Br)c2c1[nH]c1ccccc21</smiles>

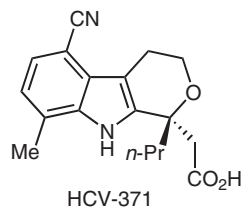

Figure 1 Examples of naturally occurring and artificial bioactive isochromans and tetrahydropyrano[3,4-b]indoles

The Pictet-Spengler reaction was discovered in 1911 and involves the $\mathrm{HCl}$-promoted condensation of $\beta$ phenethylamine and formaldehyde dimethyl acetal to form 1,2,3,4-tetrahydroisoquinoline (Scheme 1 ). ${ }^{11}$ The definition 
of the Pictet-Spengler reaction was later expanded to include cyclizations of imines or iminium ions possessing a covalently linked aryl group that undergoes substitution upon ring-closure. ${ }^{12}$ While the apparently first example of an oxa-Pictet-Spengler reaction dates back to $1935,{ }^{13}$ when the synthesis of isochroman from chloroether 1 was disclosed in a patent by Buschmann and Michel (Scheme 1), the term oxa-Pictet-Spengler cyclization was coined by
Wünsch and Zott only in $1992 .{ }^{14}$ While it was found that $\beta$ phenylethanol can condense directly with formaldehyde or paraformaldehyde in the presence of aqueous $\mathrm{HCl}$ to form isochroman without the need to first isolate 1, this approach inadvertently leads to side products containing chloromethyl groups on the phenyl ring (not shown). ${ }^{14,15} \mathrm{As}$ outlined in Scheme 1, the general mechanism of the oxaPictet-Spengler reaction involves the formation of an oxo-

\section{Biographical Sketches}
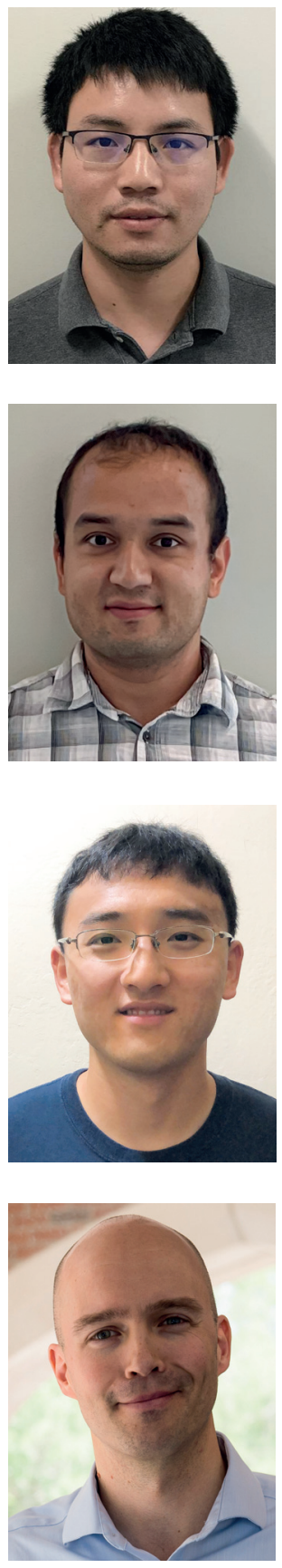

Zhengbo Zhu was born and raised in Jiangxi, China. He earned his B.Sc. degree in the Department of Chemistry and Chemical Engineering at Nanjing University working with

Alafate Adili was born and raised in Xinjiang, China. He earned his B.Sc. degree in the Department of Chemistry at the University of Science and Tech-

Chenfei Zhao was born in China in 1989 and received his B.Sc. at Wuhan University of Technology in 2012. He ob-

Daniel Seidel studied chemistry at the Friedrich-Schiller-Universität Jena, Germany, and at the University of Texas at Austin (Diplom 1998). He performed his graduate studies in the laboratory of Prof. Jonathan L.
Prof. Chengjian Zhu. In 2014, he moved to Rutgers University for his graduate studies, joining the group of Prof. Daniel Seidel. In August of 2017, he moved with the Seidel group to the Universi- ty of Florida. His research focuses on asymmetric Brønsted acid catalysis and redox-neutral $\alpha-\mathrm{C}-\mathrm{H}$ bond functionalization of cyclic amines. nology of China (USTC) working with Prof. Liu-Zhu Gong. In 2016, he started his Ph.D. research at Rutgers University under the direction of Prof. Daniel
Seidel. In August of 2017, he moved with the Seidel group to the University of Florida. His research focuses on asymmetric catalysis. tained his Ph.D. (2017) from Rutgers University working on cooperative catalysis under the direction of Prof. Daniel Seidel.
He is currently a postdoctoral researcher in Prof. Omar M. Yaghi's lab at UC Berkeley working on reticular chemistry.
Sessler, obtaining his Ph.D. in 2002. From 2002 to 2005, he was an Ernst Schering Postdoctoral Fellow in the group of Prof. David A. Evans at Harvard University. He started his independent career at Rutgers
University in 2005 and was promoted to Associate Professor in 2011 and Full Professor in 2014. In the summer of 2017, his research group moved to the University of Florida. 
carbenium ion, followed by ring closure and subsequent deprotonation/rearomatization. Both the Pictet-Spengler cyclization and the oxa-Pictet-Spengler cyclization can be viewed as variants of an intramolecular Friedel-Crafts alkylation. ${ }^{16}$ In addition, the oxa-Pictet-Spengler cyclization is mechanistically related to certain types of the Prins reaction. ${ }^{17}$

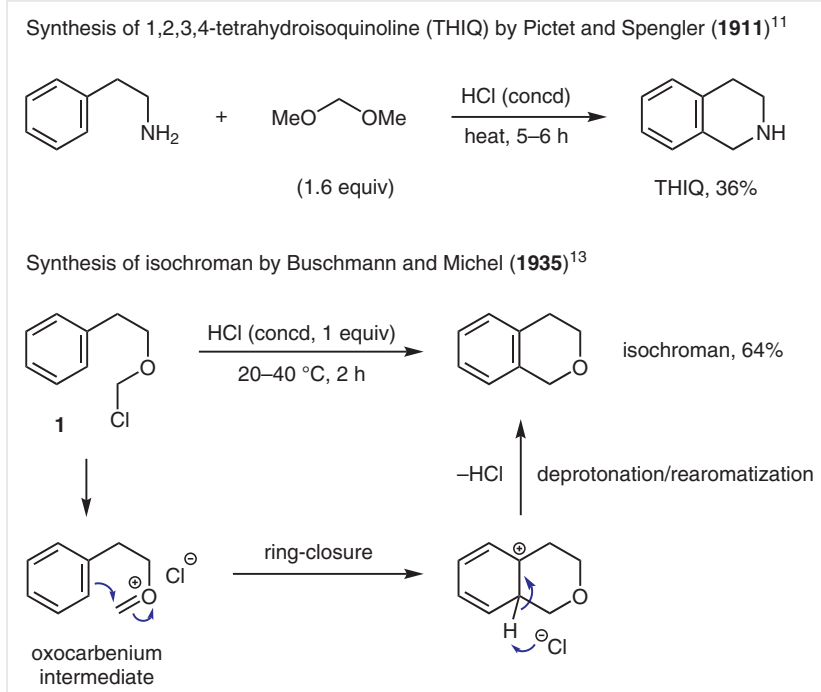

Scheme 1 Original reports on the Pictet-Spengler reaction and its oxygen analogue, along with its general mechanism

For the majority of the history of the oxa-Pictet-Spengler reaction, asymmetric variants were limited to cyclizations of enantioenriched starting materials. ${ }^{9}$ Several illustrative examples of such diastereoselective oxa-Pictet-Spengler cyclizations are provided in Scheme 2 . A chiral auxiliary based approach was reported by Costa et al., utilizing $\beta$-ketoester 3 derived from (-)- $\beta$-pinene. ${ }^{18}$ Condensation of tryptophol $(2)^{19}$ with $\beta$-ketoester $\mathbf{3}$ is facilitated by $\mathrm{SnCl}_{4}$, resulting in the formation of product 4 with excellent diastereoselectivity. Interestingly, the use of $\mathrm{BF}_{3}$ etherate in place of $\mathrm{SnCl}_{4}$ provides a 1:1 mixture of product diastereomers. The ratio of the starting materials and the amount of the Lewis acid are not specified in this report. Also, the absolute configuration of product 4 remains unknown. A highly diastereoselective oxa-Pictet-Spengler cyclization was reported by Fernandes and Brückner in the course of a synthesis of (+)kalafungin. ${ }^{20}$ Exposure of $\mathbf{5}$ to two equivalents of acetaldehyde dimethyl acetal and excess $\mathrm{BF}_{3}$ etherate provides product $\mathbf{6}$ as a single diastereomer in excellent yield. As part of their synthesis of (-)-platensimycin, Eey and Lear explored the conversion of $\mathbf{7}$ into $\mathbf{8}$ via an interesting type of oxa-Pictet-Spengler cyclization under a variety of conditions. ${ }^{21}$ Although the reaction can be facilitated with a large excess of $\mathrm{SnCl}_{4}$ (8 equiv), the optimal conditions involve exposure of 7 to a catalytic amount of $\mathrm{Bi}(\mathrm{OTf})_{3}(5 \mathrm{~mol} \%)$ in the presence of lithium perchlorate ( 3 equiv) and molecular sieves in dichloromethane at room temperature, allowing for the isolation of polycyclic product $\mathbf{8}$ in excellent yield. A recent example of a Brønsted acid catalyzed diastereoselective oxa-Pictet-Spengler cyclization was reported by Da and co-workers. ${ }^{22}$ Tryptophol derivative $\mathbf{9}$, derived from the enantioselective CBS reduction of the corresponding ketone, engages benzaldehyde dimethyl acetal in the presence of a catalytic amount of trifluoroacetic acid to furnish tetrahydropyrano[3,4-b]indole 10 in excellent yield and dr. Consistent with the expected mechanism of this transformation, the ee of product $\mathbf{1 0}$ matches that of the starting material $\mathbf{9}$.

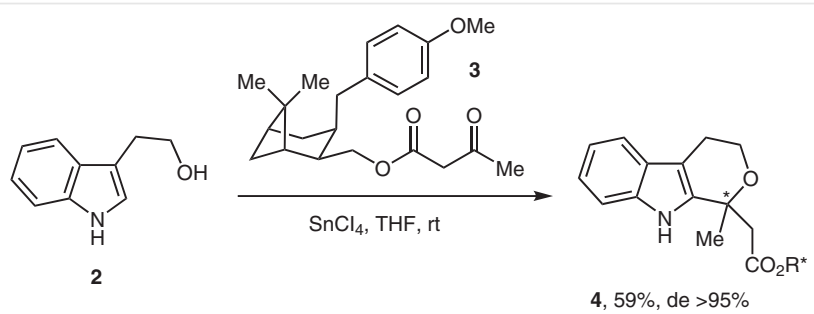<smiles>COc1c(C2OC(=O)C[C@H]2O)cc(OC)c2c(OC)cccc12</smiles>
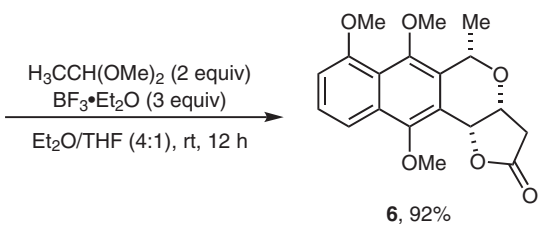<smiles>COc1ccc(C[C@@H]2C[C@H](O)O[C@@]2(C)C[O+])cc1O</smiles>
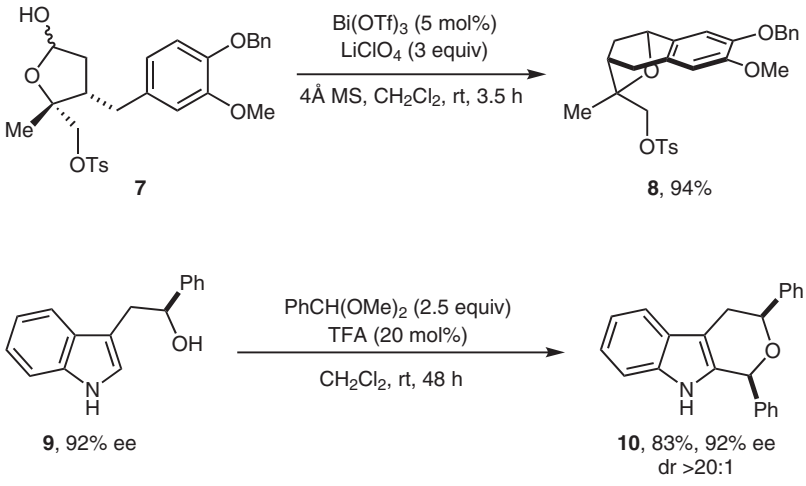

Scheme 2 Examples of diastereoselective oxa-Pictet-Spengler reactions with optically active starting materials

The first documented efforts toward developing a catalytic enantioselective variant of the oxa-Pictet-Spengler reaction were disclosed by Doyle in 2008. ${ }^{23}$ Evaluation of a number of (thio)urea catalysts in direct condensations of tryptophol with a range of aldehydes and ketones, either in the absence or presence of various Brønsted and Lewis acid additives and dehydrating agents, was reported to lead to tetrahydropyrano[3,4- $b$ ]indole products with low levels of enantioinduction ( $<15 \%$ ee, not shown). Significant increases in reactivity and appreciable levels of enantioselectivity are observed with tryptophol-derived mixed acetoxy- 
acetals such as 11; precursors that enable the formation of the requisite oxocarbenium ion intermediates under milder conditions (Scheme 3). Exposure of $\mathbf{1 1}$ to trimethylsilyl chloride in the presence of thiourea catalyst $\mathbf{1 3}$ furnishes product 12 in excellent yield and encouraging $49 \%$ ee (absolute configuration not established). Higher levels of enantioselectivity are obtained with $\mathrm{N}$-MOM protected tryptophol acetals 14 (Scheme 4). Reactions of acetals 14, performed under identical conditions, provide the corresponding products $\mathbf{1 5}$ with up to $81 \%$ ee (absolute configuration of products not established). Promising preliminary results for catalytic enantioselective oxa-Pictet-Spengler cyclizations were also obtained with acetoxy-acetals derived from a number of $\beta$-heteroaryl ethanols (Scheme 5). Regarding the mechanism of these transformations, the hydrogen-bond donor ${ }^{24}$ thiourea catalyst most likely interacts with chloride via anion-binding, ${ }^{25}$ forming a chiral ion pair with the oxocarbenium ion.

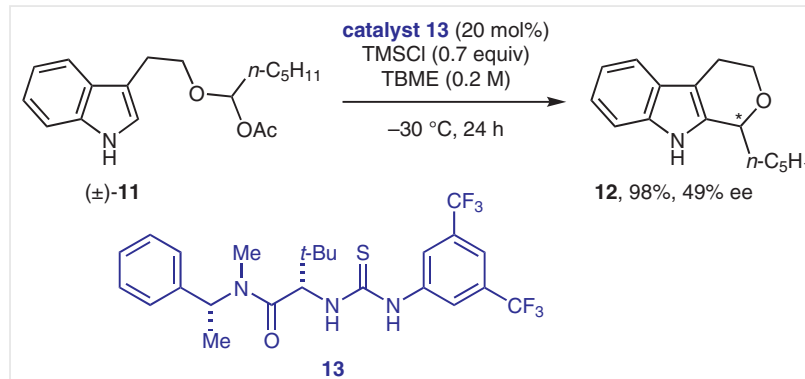

Scheme 3 Thiourea-catalyzed enantioselective oxa-Pictet-Spengler cyclization with mixed acetals derived from tryptophol

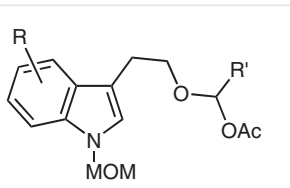

14

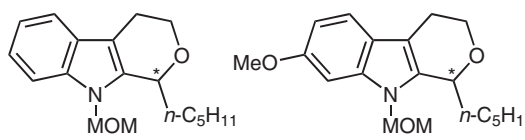

$15 a, 88 \%, 73 \%$ ee

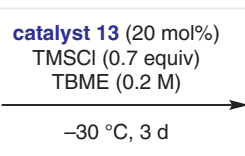

$-30{ }^{\circ} \mathrm{C}, 3 \mathrm{~d}$

15b, $95 \%, 69 \%$ ee

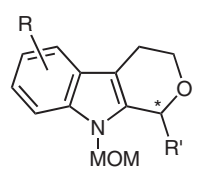

15

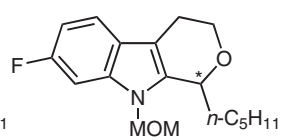

$15 \mathrm{c}, 89 \%, 81 \%$ ee
Scheme 4 Thiourea-catalyzed enantioselective oxa-Pictet-Spengler cyclization with $\mathrm{N}$-MOM protected tryptophol acetals, selected scope

Another early example of a catalytic enantioselective oxa-Pictet-Spengler cyclization was reported by Scheidt and co-workers in 2013 (Scheme 6). ${ }^{26}$ Chiral phosphoric acid catalyst $\mathbf{1 9}$ is capable of converting preformed enol

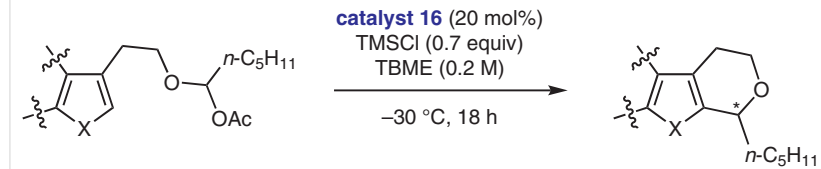<smiles>CC(C)C(NC(=S)Nc1cc(C(F)(F)F)cc(C(F)(F)F)c1)C(=O)N(C)C(C)c1ccccc1</smiles>

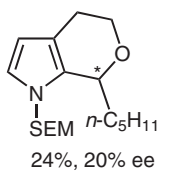

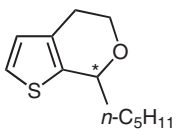

$20 \%$ conv., $16 \%$ ee

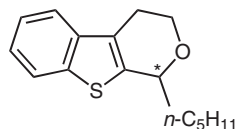

$20 \%$ conv., $35 \%$ ee

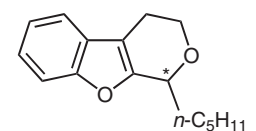

$35 \%$ conv., $55 \%$ ee
Scheme 5 Thiourea-catalyzed enantioselective oxa-Pictet-Spengler cyclizations involving various heterocycles

ether $\mathbf{1 7}$ into the corresponding cyclization product 18 with a moderate level of enantiocontrol (absolute configuration not established). Here, the intermediate oxocarbenium ion is generated by protonation of enol ether $\mathbf{1 7}$ by the chiral Brønsted acid 19. ${ }^{27}$<smiles>C/C=C\OCCn1cc(-c2ccccc2)c2ccccc21</smiles>

17

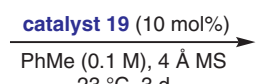
$23^{\circ} \mathrm{C}, 3 \mathrm{~d}$<smiles>O=P(O)(O)Oc1c(Br)cc2ccccc2c1-c1c(Br)cc2ccccc2c1Br</smiles>

$19\left[\mathrm{Ar}=3,5-\left(\mathrm{CF}_{3}\right)_{2}-\mathrm{C}_{6} \mathrm{H}_{3}\right]$

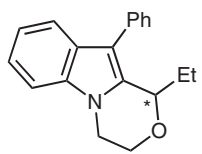

$18,75 \%, 60 \%$ ee
Scheme 6 Brønsted acid catalyzed enantioselective oxa-PictetSpengler cyclization with a preformed enol ether

Shortly thereafter, Nielsen and co-workers reported a related approach in which enol ethers are generated in situ from allyl ethers via a ruthenium catalyzed isomerization process (Scheme 7). ${ }^{28}$ Application of this strategy to allyl ether 20, in the presence of chiral imidodiphosphoric acid 22, furnishes product $\mathbf{2 1}$ in good yield. While the enantioselectivity achieved in this reaction is only moderate (absolute configuration not established), this is the only example thus far that generates a tetrasubstituted stereogenic center in the course of an oxa-Pictet-Spengler cyclization. The $E / Z$ selectivity of the initial isomerization step is unknown. 
<smiles>C=CC(C)OCCc1c[nH]c2ccccc12</smiles>

20, racemic catalyst $22(5 \mathrm{~mol} \%)$ $\mathrm{RuHCl}(\mathrm{CO})\left(\mathrm{PPh}_{3}\right)_{3}(5 \mathrm{~mol} \%)$ $\mathrm{PhMe}$, reflux, $1 \mathrm{~h}$<smiles>O=P(O)(O)Oc1c(-c2c(OP(O)(N=C(Br)c3cc4ccccc4cc3Br)=NP(=O)(O)c3cccc4ccccc34)c(Br)cc3ccccc23)c(Br)cc2ccccc12</smiles>

$22\left(\mathrm{Ar}=2-i-\mathrm{Pr}-5-\mathrm{Me}-\mathrm{C}_{6} \mathrm{H}_{3}\right)$

Scheme 7 Dually catalyzed enantioselective oxa-Pictet-Spengler cyclization of an allyl ether

The first highly enantioselective catalytic oxa-PictetSpengler cyclization was reported by our group in 2016 (Scheme 8). ${ }^{29}$ In the presence of thiourea catalyst $\mathbf{2 4}$ and ammonium salt catalyst 25, tryptophol (2) undergoes an oxa-Pictet-Spengler reaction with benzaldehyde to form product 23a in excellent yield and ee. Substituted benzaldehydes also participate in this reaction. While para-substituted benzaldehydes provide products with excellent ee, meta-substitution leads to a slight drop-off in enantioselectivity, and ortho-substitution results in a significant erosion of ee (e.g., product 23f). Substitution of the indole ring is compatible with the catalytic system, whereas aliphatic aldehydes are not viable reaction partners. Mechanistically, this method is based on a dual catalysis strategy that avoids the need for strongly acidic conditions commonly required for accessing oxocarbenium ions via direct condensation of aldehydes and alcohols. The ammonium salt catalyst $\mathbf{2 5}$ is thought to first engage the aldehyde to form an iminium ion $^{30}$ that then reacts with tryptophol, ultimately resulting in the formation of an oxocarbenium ion that likely interacts with the catalyst via anion-binding. A plausible transition state for the key C-C bond-forming step is shown in Scheme 8 . This model is supported by the following observations: (1) there is a strong dependence on the nature of the anion with regard to reactivity and product ee; (2) The enantioselectivity of the reaction is solely dependent on catalyst $\mathbf{2 4}$ (e.g., almost identical results are obtained with the enantiomer of $\mathbf{2 5}$ or racemic 25), and (3) The reaction with $N$-methyl tryptophol provides racemic product (e.g., product 23k), indicating an important interaction of the indole $\mathrm{N}-\mathrm{H}$ with a hydrogen-bond acceptor site on the catalyst (e.g., the S-atom of the electron-rich thiourea moiety) in the enantio-determining step of the reaction. Interestingly, catalyst $\mathbf{2 5}$ can be replaced with $\mathrm{HCl}$ to provide the product with nearly identical ee but in a significantly more sluggish reaction.

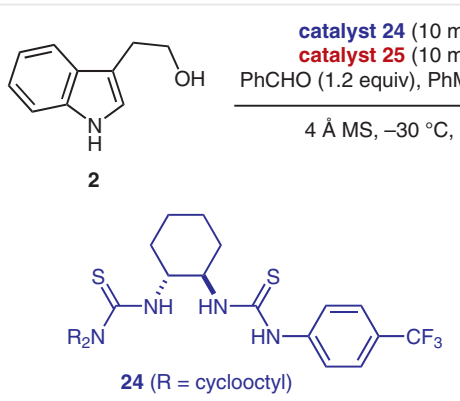

Selected scope:
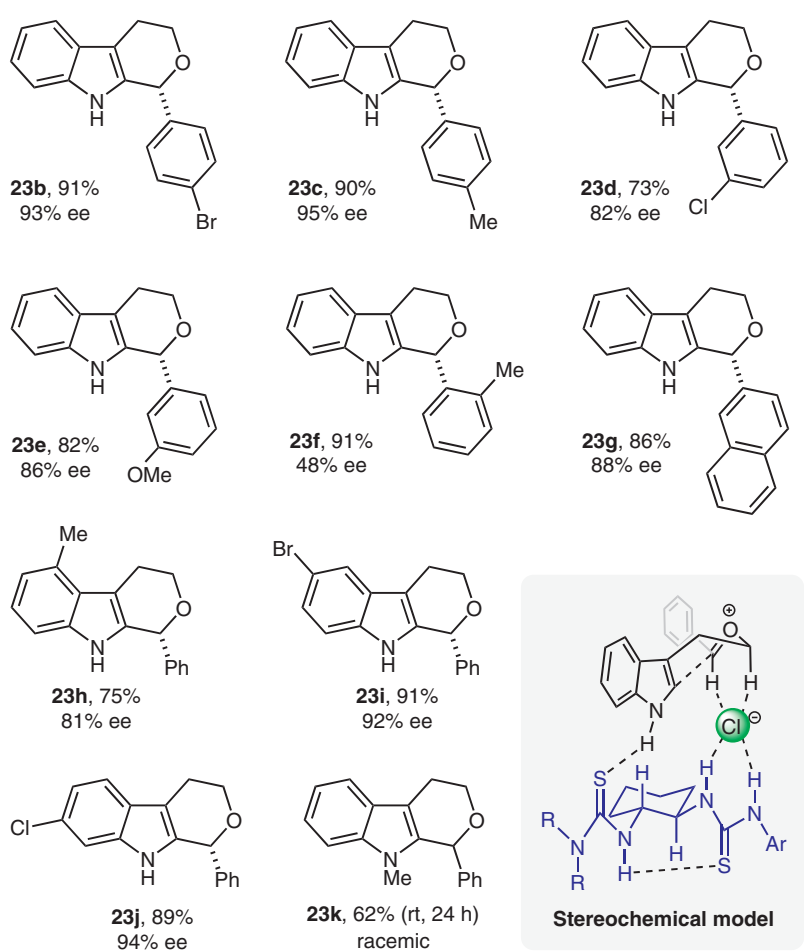
racemic

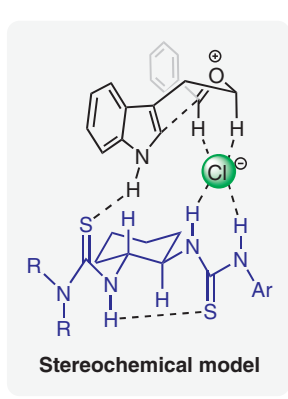

Scheme 8 Dually catalyzed enantioselective oxa-Pictet-Spengler reactions of tryptophols with aldehydes

Nearly simultaneously to our report, the List group reported a distinct strategy for realizing highly enantioselective oxa-Pictet-Spengler cyclizations (Scheme 9). ${ }^{31}$ Nitrated imidodiphosphoric acid catalyst $\mathbf{2 8}$ was found to efficiently catalyze reactions of hydroxy-substituted $\beta$-phenylethanols with aldehydes. Catalyst $\mathbf{2 8}$ is significantly more active than the analogous imidodiphosphoric acid catalyst lacking the two nitro groups. The corresponding BINOL-based phosphoric acid 29 is also a competent catalyst but affords the products with significantly lower levels of enantioselectivity. Catalyst $\mathbf{2 8}$ provides products $\mathbf{2 7}$ with excellent ee values while accommodating a range of aromatic and aliphatic aldehydes, with the latter requiring elevated reaction 
temperatures $\left(50^{\circ} \mathrm{C}\right)$. An additional methoxy group on 26a is also tolerated. The proposed transition state for the $\mathrm{C}-\mathrm{C}$ bond-forming step involves a critical hydrogen-bonding interaction of the catalyst anion with the phenol O-H moiety, as elucidated by DFT calculations. An alternate transition state in which ring-closure occurs in ortho- rather than para-position of the phenol $\mathrm{O}-\mathrm{H}$ moiety was calculated to be $6.3 \mathrm{kcal} / \mathrm{mol}$ higher in free energy (not shown). Consistent with these calculations, these regioisomers are not observed.<smiles>O=[N+]([O-])c1ccc(-c2ccc([N+](=O)[O-])cc2)cc1</smiles>

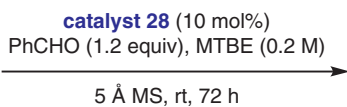

$5 \AA ̊ n S, ~ r t, 72 \mathrm{~h}$

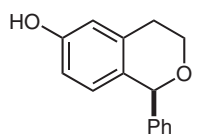

27a, $91 \%, 96 \%$ ee<smiles></smiles>

$28\left(\mathrm{Ar}=2,4,6-\mathrm{Et}_{3}-\mathrm{C}_{6} \mathrm{H}_{2}\right)$ 27b, $81 \%, 95 \%$ ee<smiles>CCCCC1OCCc2cc(O)ccc21</smiles>

27c, $82 \%, 96 \%$ ee

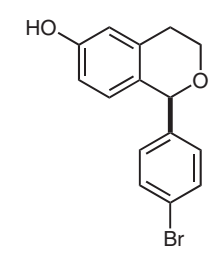

27d, $87 \%, 99 \%$ ee<smiles>Oc1ccc2c(c1)CCOC2c1cccc(Br)c1</smiles>

27e, $75 \%, 98 \%$ ee<smiles>Oc1ccc2c(c1)CCOC2c1cccc2ccccc12</smiles>

27f, $73 \%, 90 \%$ ee<smiles>COc1cccc(C2OCCc3cc(O)ccc32)c1</smiles>

27g, $93 \%, 96 \%$ ee

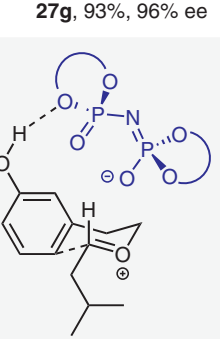

Calculated TS

Scheme 9 Imidodiphosphoric acid catalyzed enantioselective oxaPictet-Spengler reactions of hydroxy-substituted $\beta$-phenylethanols with aldehydes

Interesting observations were made in the course of the List study, outlining remaining challenges (Scheme 10). Consistent with the calculated transition state depicted in Scheme 9, the presence of a 3-hydroxy substituent on the $\beta$-phenylethanol is a strict requirement. In the presence of

catalyst 29, $\beta$-phenylethanols $\mathbf{2 6 b}$-d react with aldehydes to provide symmetrical acetals $\mathbf{3 0}$ as the only products. On the other hand, the 2-hydroxy substrate $\mathbf{3 1}$ undergoes formation of seven-membered cyclic acetal 32, whereas 33 affords complex mixtures in reactions with aldehydes.

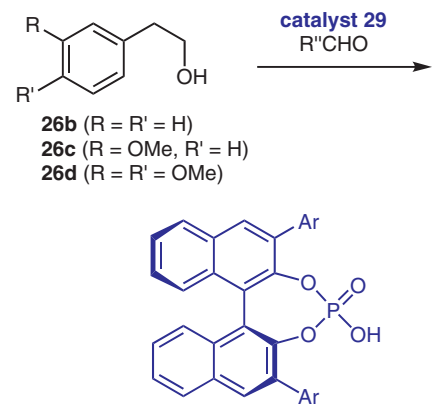

$29\left(\mathrm{Ar}=2,4,6-\mathrm{Et}_{3}-\mathrm{C}_{6} \mathrm{H}_{2}\right)$<smiles>OCCc1ccccc1O</smiles>

31<smiles>OCCc1ccc(O)cc1</smiles>

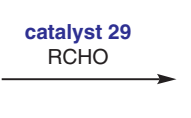

catalyst 29 $\mathrm{RCHO}$<smiles>[R]c1ccc(CCOC([B])OCCc2ccc([R])c([R])c2)cc1</smiles><smiles>[R]c1cc2c(cc1[R])C(P)OCC2</smiles>

27 (not observed)<smiles>[R]C1OCCc2ccccc2O1</smiles>

32
Scheme 10 Current limitations in oxa-Pictet-Spengler reactions with $\beta$-phenylethanols

In 2018, Scheidt and co-workers published an alternate strategy to access tetrahydropyrano[3,4-b]indoles in highly enantioenriched form. ${ }^{32} \mathrm{~A}$ combination of chiral phosphoric acid catalyst $\mathbf{3 6}$ and achiral urea catalyst $\mathbf{3 7}$ facilitates cyclizations of tryptophol-derived enol ethers such as 34a to generate oxa-Pictet-Spengler products with high levels of enantioselectivity (e.g., 35a). The presence of a urea-type protecting group on the tryptophol nitrogen is a crucial design element of this approach (vide infra). While chiral phosphoric acid $\mathbf{3 6}$ is capable of catalyzing the reaction in the absence of urea 37, reaction rates are dramatically retarded (incomplete reaction after $18 \mathrm{~h}$ vs. complete reaction within $15 \mathrm{~min}$ ) and afford product 35a in only 36\% ee (not shown). Regarding the scope of this transformation, substitution of different indole ring positions is readily accommodated. While most products contain a gem-dimethyl group adjacent to the tetrahydropyrano oxygen atom, products lacking these substituents are also obtained with excellent ee values. Interestingly, this study contains the only example thus far reported in which a seven-membered ring is constructed enantioselectively in the course of an oxa-Pictet-Spengler cyclization, albeit in only 32\% ee (product 35i). As an application of their method, the authors reported a facile synthesis of coixspirolactam $\mathrm{C}$ from oxa-Pictet- 
Spengler product $\mathbf{3 5 h}$. Regarding the mechanism of this transformation, it was proposed that a network of hydrogen-bonding interactions is responsible for achieving high levels of reactivity and enantiocontrol (see proposed TS in Scheme 11). Specifically, the thiourea catalyst is thought to bind to the chiral phosphate anion via dual hydrogen bonding while engaging in an additional hydrogen-bonding interaction with the carbonyl group of the protonated substrate.

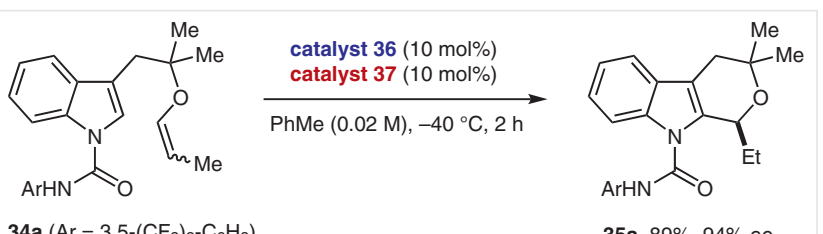<smiles>O=P(O)(O)Oc1c(Br)cc2ccccc2c1-c1c(Br)cc2ccccc2c1Br</smiles>

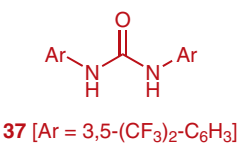

$36\left[\mathrm{Ar}=3,5-\left(\mathrm{CF}_{3}\right)_{2}-\mathrm{C}_{6} \mathrm{H}_{3}\right]$

Selected scope:<smiles>CCCCNC(=O)n1c2c(c3c(F)cccc31)C(CC)OC(C)([N+](C)(C)C)C2</smiles>

35b, $73 \%, 84 \%$ ee<smiles>CCCCCCCNC(=O)n1c2c(c3cc(Cl)ccc31)CC(C)([N+](=O)[O-])OC2CC</smiles>

35 c, $88 \%, 94 \%$ ee

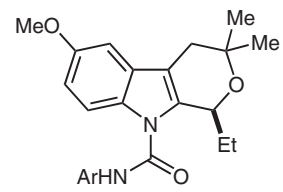

$35 \mathrm{~d}, 90 \%, 92 \%$ ee

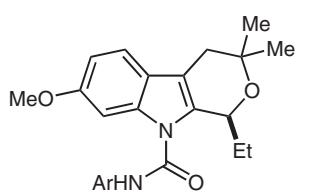

35 e, $93 \%, 90 \%$ ee

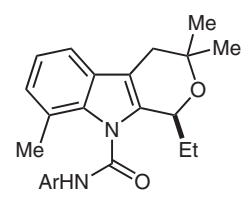

$35 \mathrm{f}, 89 \%, 60 \%$ ee

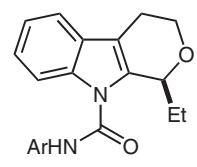

$35 \mathrm{~g}, 54 \%, 96 \%$ ee

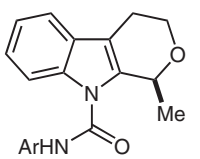

35h, $76 \%, 94 \%$ ee

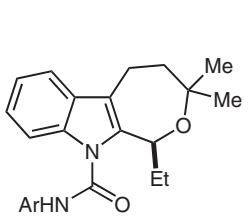

$35 i, 64 \%, 32 \%$ ee

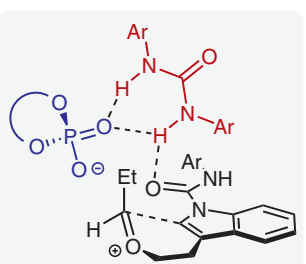

Proposed TS
Scheme 11 Dually catalyzed enantioselective oxa-Pictet-Spengler reactions of tryptophol-derived enol ethers
While not aiming to be complete, the following section provides an overview of catalytic enantioselective reactions that lead to oxa-Pictet-Spengler type products by alternate pathways also involving the intermediacy of oxocarbenium ions. As exemplified in the synthesis of enantioenriched isochromans, nucleophilic additions to cyclic oxocarbenium ions provide an alternative to the oxa-Pictet-Spengler cyclization (Figure 2). While cyclic isochroman-type oxocarbenium ions are more stable than their corresponding acyclic counterparts by virtue of conjugation with the fused and necessarily coplanar aryl ring, they offer an expanded array of opportunities for designing enantioselective variants. To render oxa-Pictet-Spengler cyclizations catalytic and enantioselective, the anion $\mathrm{X}^{-}$has to be homochiral (e.g., conjugate base of a chiral Brønsted acid catalyst). Alternatively, if achiral, $\mathrm{X}^{-}$has to be tightly associated with a chiral anion receptor catalyst (or catalyst ensemble) in order to facilitate the ring-closure step in an enantioselective fashion. These modes of enantiocontrol are also available in nucleophilic additions to cyclic oxocarbenium ions. In addition, the otherwise achiral nucleophile can be rendered chiral by interaction with a chiral catalyst. Nucleophiles can be carbon- or heteroatom-based, enabling the formation of monosubstituted isochromans via a reductive process.

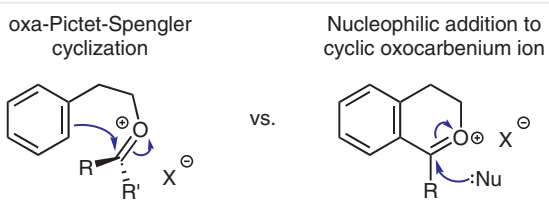

Figure 2 Different pathways to enantioenriched isochromans.

A 2008 landmark study by the Jacobsen group accomplished the first catalytic enantioselective synthesis of 1substituted isochromans (Scheme 12). ${ }^{33,34}$ Treatment of isochroman-derived acetal $\mathbf{3 8}$ with $\mathrm{BCl}_{3}$ results in the in situ formation of 1-chloroisochroman (not shown), which is then converted into product 39a upon treatment with silyl ketene acetal $\mathbf{4 1}$ in the presence of thiourea catalyst $\mathbf{4 0}$. Binding of the chloride counter anion of the transient oxocarbenium ion to thiourea catalyst $\mathbf{4 0}$ is thought to form a chiral ion pair responsible for controlling the facial selectivity in the silyl ketene acetal addition step. Isochromans containing substituents on different positions of the aryl ring and a range of silyl ketene acetals participate in this transformation to provide products $\mathbf{3 9}$ in good yields and excellent ee values. 


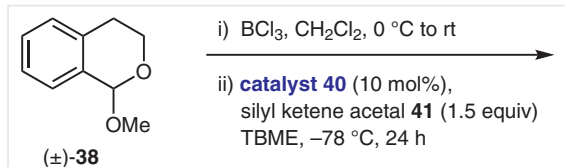<smiles>CC(C)(C)[C@H](NC(=S)Nc1cc(C(F)(F)F)cc(C(F)(F)F)c1)C(=O)N1CCCC1c1ccc(F)cc1</smiles>

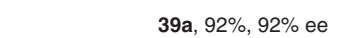

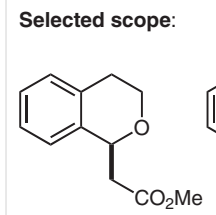<smiles>CC(=O)CC1OCCc2c(O)cccc21</smiles><smiles>COCC1OCCc2ccc(N)cc21</smiles>
39b, $87 \%, 85 \%$ ee 39 c, $71 \%, 90 \%$ ee 39d, $70 \%, 90 \%$ ee $\quad 39 e, 82 \%, 87 \%$ ee
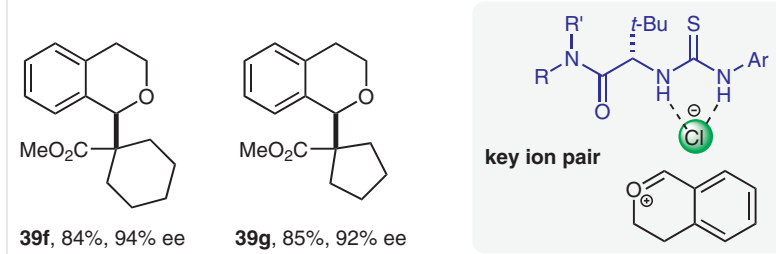

39f, $84 \%, 94 \%$ ee

39g, $85 \%, 92 \%$ ee

Scheme 12 Catalytic enantioselective additions of silyl ketene acetals to cyclic oxocarbenium ions

In 2011, Watson and co-workers reported a conceptually different strategy for the catalytic enantioselective addition of nucleophiles to isochroman-derived oxocarbenium ions (Scheme 13). ${ }^{35}$ Specifically, catalytic enantioselective alkynylation of acetal $\mathbf{3 8}$ with phenylacetylene is achieved with a $\mathrm{Cu}(\mathrm{I})$ complex of bisoxazoline ligand 43. Hünig's base facilitates the formation of a chiral $\mathrm{Cu}$ acetylide complex that adds to the oxocarbenium ion derived from acetal 38 and TMSOTf. The reaction tolerates substituents on different positions of the isochroman aryl ring and is applicable to a range of terminal alkynes. Some products are somewhat sensitive to oxidative decomposition (e.g., lactone formation). This is particularly true for product $\mathbf{4 2 h}$ (the yield shown corresponds to the product obtained from subsequent reduction of the alkyne moiety to the corresponding alkane via hydrogenation). An impressive extension of this chemistry was reported in 2015 (Scheme 14). ${ }^{36}$ A modified catalyst system derived from Pybox ligand 46 enables the synthesis of highly enantioenriched isochromans 45 from 1-substituted isochroman ketals $\mathbf{4 4}$. This is a rare example
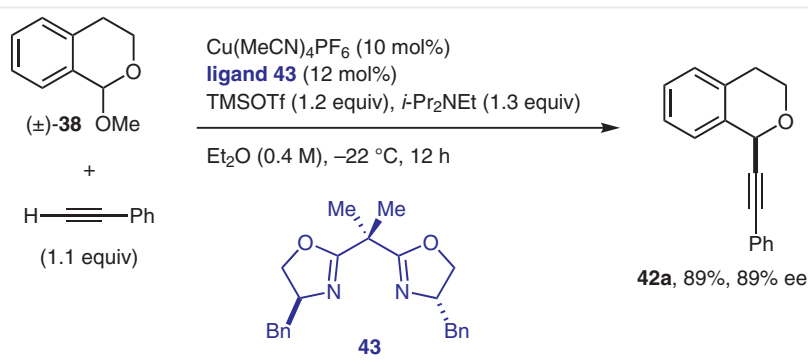

42a, $89 \%, 89 \%$ ee<smiles>Cc1ccccc1C#CC1OCCc2ccccc21</smiles>

42b, $83 \%, 91 \%$ ee<smiles>Clc1cccc(C#CC2OCCc3ccccc32)c1</smiles>

42c, $73 \%, 85 \%$ ee<smiles>FC(F)(F)c1ccc(C#CC2OCCc3ccccc32)cc1</smiles><smiles>C(#CC1OCCc2ccccc21)C1=CCCCC1</smiles>

42e, $64 \%, 67 \%$ ee 42d, $77 \%, 87 \%$ ee<smiles>C(#CC1OCCc2cc3ccccc3cc21)c1ccccc1</smiles>

42f, $73 \%, 94 \%$ ee

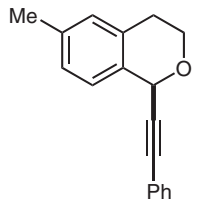

42g, $88 \%, 87 \%$ ee

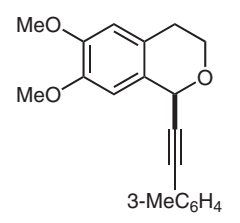

42h, $50 \%$, $85 \%$ ee

Scheme 13 Catalytic enantioselective alkynylation of isochromanderived oxocarbenium ions

of a catalytic enantioselective process generating isochromans containing challenging tetrasubstituted stereogenic centers.

Acetals such as $\mathbf{3 8}$ are typically obtained from their corresponding isochromans via an oxidative process. In 2014, the Liu group reported a strategy that obviates the need for preparing acetals in a separate step (Scheme 15). ${ }^{37,38}$ Oxocarbenium ions are accessed in situ by oxidation of isochromans with 2,3-dichloro-5,6-dicyano-1,4-benzoquinone (DDQ). Addition of the aldehyde substrate is facilitated by catalyst 48 via an enamine mechanism. Reduction of the initially formed aldehyde products with sodium borohydride provides substituted isochromans (e.g., 47a-g) and related products with excellent levels of enantioselectivity, albeit with moderate diastereoselectivity. As part of this study, the Liu group achieved the catalytic enantioselective addition of boronic ester $\mathbf{5 1}$ to isochroman (Scheme 16). This reaction is facilitated by tartaric-acid-derived catalyst $\mathbf{5 0}$ and provides product $\mathbf{4 9}$ with moderate ee after hydrogenation in situ. ${ }^{39}$ 


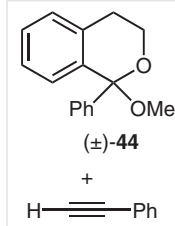

(1.2 equiv)<smiles>CN(C)C1=NCCCN1CCCN1CCCCC1c1ccccc1</smiles>

CuSPh (10 mol\%), ligand 46 (12 mol\%) MTBD (1.55 equiv), $\mathrm{BF}_{3} \cdot \mathrm{OEt}_{2}$ (2 equiv) $\mathrm{Et}_{2} \mathrm{O}(0.15 \mathrm{M}), 4^{\circ} \mathrm{C}, 48 \mathrm{~h}$

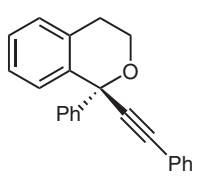

45a, $92 \%, 78 \%$ ee

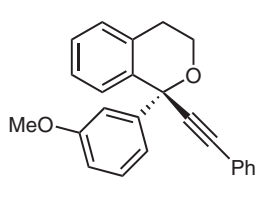

$45 c, 86 \%, 96 \%$ ee

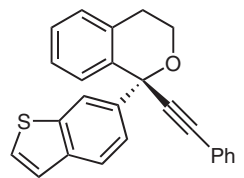

45d, $71 \%, 87 \%$ ee

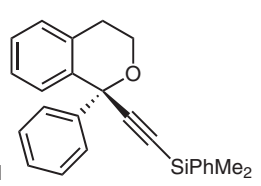

$45 f, 53 \%, 81 \%$ ee

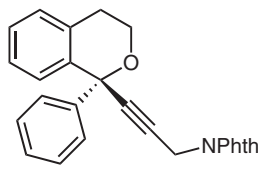

45g, $80 \%, 93 \%$ ee

45 e, $87 \%, 97 \%$ ee

Scheme 14 Formation of tetrasubstituted stereogenic centers via catalytic enantioselective alkynylation of isochroman-derived oxocarbenium ions

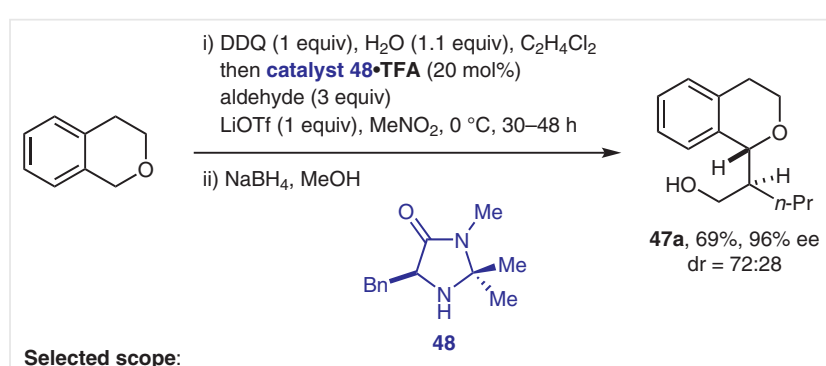

Selected scope:

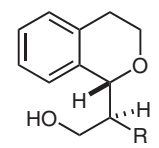

47b $(R=M e), 66 \%, 93 \%$ ee, $d r=69: 31$ $47 \mathrm{c}(\mathrm{R}=\mathrm{Bn}), 79 \%, 96 \%$ ee, $d r=73: 27$ 47d $(R=P M B), 73 \%, 95 \%$ ee, $d r=75: 25$ 47e $\left(\mathrm{R}=\mathrm{C}_{4} \mathrm{H}_{8} \mathrm{OBn}\right), 63 \%, 90 \%$ ee, $\mathrm{dr}=71: 29$ $47 f\left(R=\mathrm{C}_{4} \mathrm{H}_{8} \mathrm{OTBS}\right), 65 \%, 94 \%$ ee, $d r=70: 30$

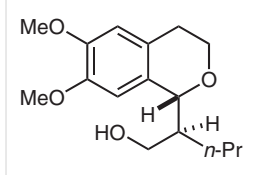

$47 \mathrm{~g}, 92 \%, 96 \%$ ee $\mathrm{dr}=79: 21$

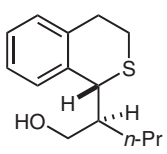

47h, $85 \%, 90 \%$ ee $d r=67: 33$

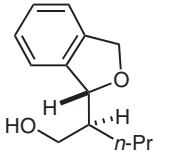

47i, 55\%, 96\% ee $\mathrm{dr}=63: 37$

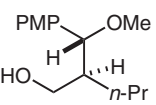

47j not formed

Scheme 15 Catalytic enantioselective addition of enolizable aldehydes to isochromans

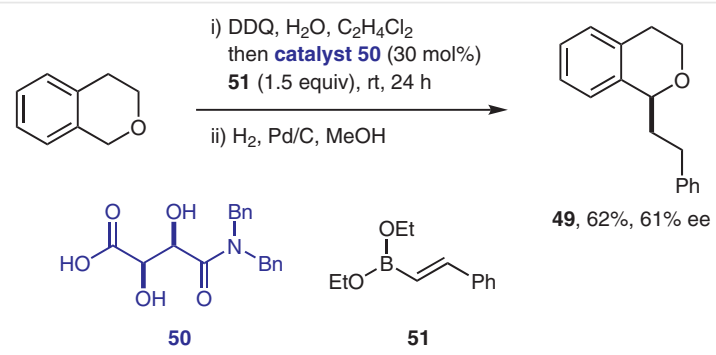

Scheme 16 Catalytic enantioselective addition of a boronic ester to isochroman

In 2017, the Liu group reported an interesting redox deracemization strategy that provides highly enantioenriched isochromans 52 (Scheme 17). ${ }^{40}$ Racemic starting materials such as $( \pm)-52 a$ are oxidized in situ by DDQ to the corresponding oxocarbenium ions, which initially form acetals in the presence of methanol. The subsequent reduction step with Hantzsch ester $\mathbf{5 4}$ is rendered enantioselective by imidodiphosphoric acid catalyst 53. In a subsequent study, similar products were obtained by reduction of preformed racemic acetals (not shown). ${ }^{41}$ Products 52a could potentially be obtained more directly via an oxa-Pictet-Spengler cyclization from the corresponding $\beta$-phenylethanols. However, current limitations make this an elusive goal (see discussion centered around Scheme 10). The Liu group further applied their redox deracemization strategy to the synthesis of highly enantioenriched tetrahydropyrano[3,4-b]indoles, as highlighted in Scheme $18 .^{42}$ For these substrates, SPINOL-derived phosphoric acid $\mathbf{5 5}$ and Hantzsch ester $\mathbf{5 6}$ provide optimal results. Tetrahydropyrano[3,4-b]indoles containing an aryl substituent are typically obtained in excellent yields and ee values. Unfortunately, just like the previously discussed oxa-Pictet-Spengler reaction of tryptophol is incompatible with aliphatic aldehydes (see Scheme 8 ), the deracemization process does not tolerate 1-alkyl substituents as these substrates fail to undergo oxidation under the standard reaction conditions.

Another strategy for synthesizing enantioenriched isochromans, different from everything discussed thus far, involves reactions in which the enantio-determining step is $\mathrm{C}-\mathrm{O}$ bond formation. Scheme 19 highlights seminal work in this area, published by Kitamura and co-workers in 2011. ${ }^{43}$ Ruthenium complex 59, at a catalyst loading of only 0.1 $\mathrm{mol} \%$, facilitates intramolecular dehydrative $O$-allylation of $\mathbf{5 7}$ to furnish 1-vinyl isochroman 58a in excellent yield and ee in a sequence that proceeds via the intermediacy of a Ru$\pi$-allyl species.

A mechanistically distinct approach published by White and co-workers in 2016 accomplishes the synthesis of related isochroman products by intramolecular catalytic enantioselective allylic C-H oxidation (Scheme 20). ${ }^{44} \mathrm{~A}$ 


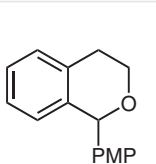

DDQ (1.05 equiv), $\mathrm{MeOH}$ ( 3 equiv) then catalyst $53(5 \mathrm{~mol} \%)$ 54 (1.4 equiv), $\mathrm{Na}_{2} \mathrm{CO}_{3}$ ( 0.5 equiv) $\mathrm{CH}_{2} \mathrm{Cl}_{2} / \mathrm{PhMe}, 5 \AA \mathrm{AS},-10^{\circ} \mathrm{C}$ $( \pm)-52 a$<smiles>O=P(O)(N=P1(O)Oc2c(Br)cc3ccccc3c2-c2c(c(Br)cc3ccccc23)O1)Oc1c(Br)cc2ccccc2c1-c1c(Br)cc2ccccc2c1Br</smiles>
$53\left(\mathrm{Ar}=3,5-\left(\mathrm{CF}_{3}\right)_{2}-\mathrm{C}_{6} \mathrm{H}_{3}\right)$

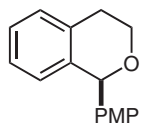

52a, $90 \%$, 90\% ee<smiles>CCOC(=O)C1=C(C)NC(C)=C(C(=O)OCC)C1</smiles>

54<smiles>CSc1ccc(C2OCCc3ccccc32)cc1</smiles><smiles>COc1ccc(C2OCCc3ccccc32)cc1OC</smiles><smiles>COc1ccc(C2OCCc3cc(OC(C)=O)c(OC(C)=O)cc32)cc1</smiles><smiles>CC(=O)Oc1ccc2c(c1)CCOC2c1ccc(Br)cc1</smiles>

52b, $91 \%, 90 \%$ ee $\quad$ 52c, $80 \%, 91 \%$ ee $\quad \mathbf{5 2 d}, 93 \%, 92 \%$ ee $\quad \mathbf{5 2 e}, 70 \%, 73 \%$ ee

Scheme 17 Catalytic redox deracemization of isochromans

complex derived from palladium acetate and ligand $\mathbf{6 1}$, in the presence of diphenylphosphinic acid, catalyzes the transformation of $\beta$-arylethanols such as $\mathbf{6 0}$ to 1 -vinyl isochromans 58, and the products are obtained with excellent levels of enantioselectivity. 2,6-Dimethylbenzoquinone $(2,6-D M B Q)$ serves as the terminal oxidant in this process.

The catalytic enantioselective synthesis of 1-alkynyl isochromans was reported by Nishibayashi and co-workers in 2019 (Scheme 21). ${ }^{45}$ A Cu(I)-complex derived from Pybox ligand 46 catalyzes the enantioselective intramolecular etherification of propargylic esters (e.g., 62) to provide products 63 in good to excellent yields and ee values. A nonlinear relationship exists between the enantiopurity of ligand 46 and product, leading the authors to propose the intermediacy of a dicopper-allenylidene species.

In 2015, Ghorai and co-workers reported a catalytic enantioselective method for the synthesis of highly enantioenriched 1-substituted isochromans (Scheme 22). ${ }^{46}$ This method is based on intramolecular conjugate addition. Reduction of the aldehyde functionality of ketoaldehydes such as 64 by pinacolborane ( $\mathrm{pinBH}$ ) provides an alkoxyboronate intermediate that then undergoes conjugate addition to form products 65 with excellent ee values. Reactions are catalyzed by quinine-derived squaramide-containing bifunctional organocatalyst $\mathbf{6 6}$ and exhibit a broad scope. This method also enables the synthesis of isochromans containing a substituent in the 3-position. An example is pro-

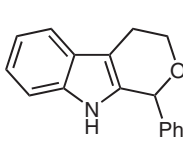

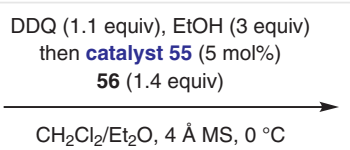

$( \pm)-23 a$

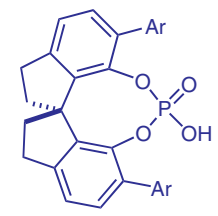

$55(\mathrm{Ar}=9$-phenanthryl $)$

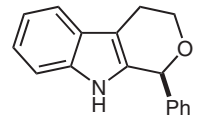

23a, $90 \%, 95 \%$ ee

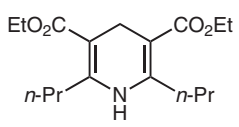

56
Selected scope:
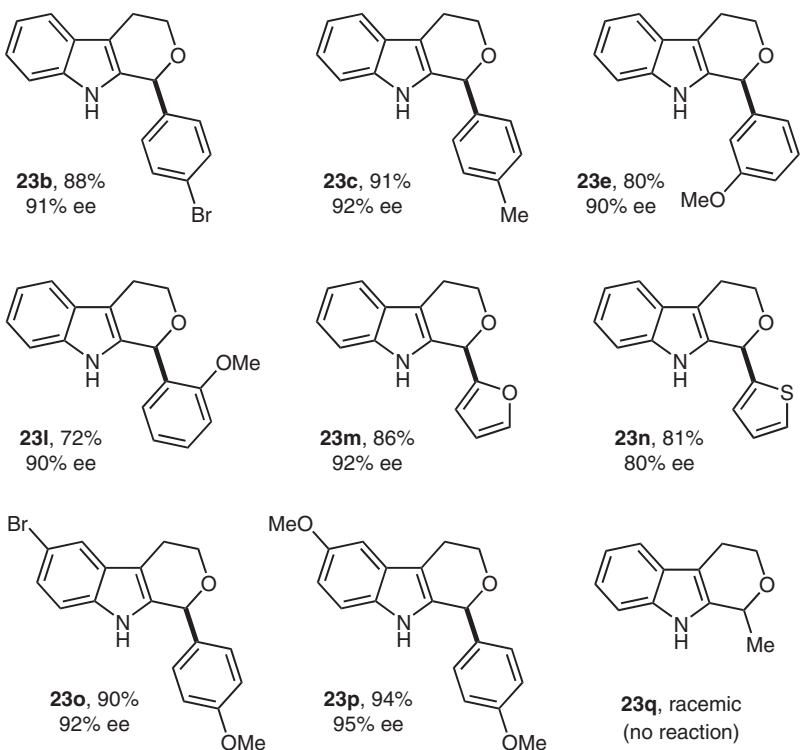

$\mathrm{MeO}$

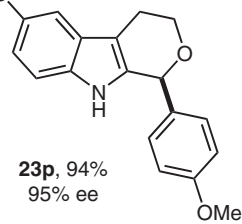

Scheme 18 Catalytic redox deracemization of tetrahydropyrano$[3,4-b]$ indoles

vided in Scheme 23. Ketoaldehyde 67, a constitutional isomer of 64, undergoes reduction followed by intramolecular conjugate addition to provide product $\mathbf{6 8}$ in $81 \%$ ee.

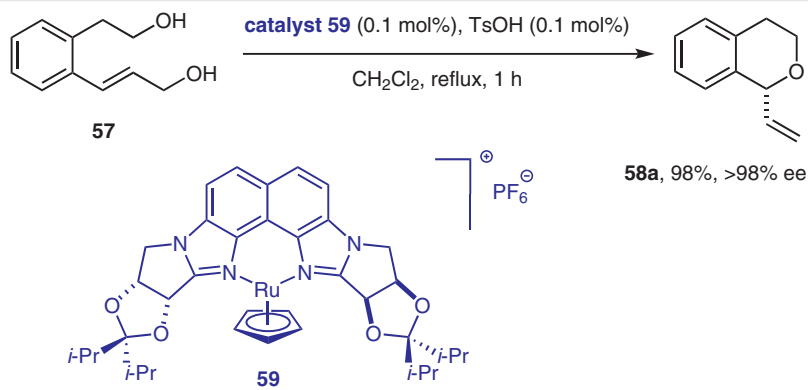

Scheme 19 Synthesis of enantioenriched isochromans via intramolecular dehydrative $\mathrm{O}$-allylation 


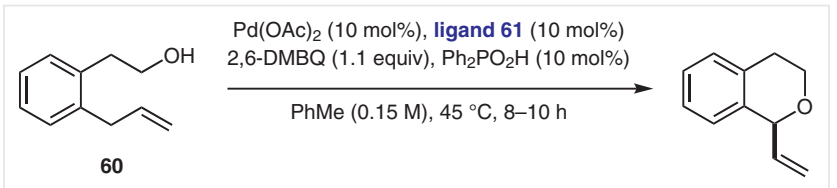<smiles>CC(C)(C)c1ccc(S(=O)(=O)c2ccccc2C2=N[C@H](c3ccccc3)CO2)cc1</smiles><smiles>CC(=O)OC1=CC(=O)C=C(C)C1=O</smiles><smiles>C=CC1OCCc2cc(OC)ccc21</smiles><smiles>C=CC1OCCc2ccc(C)cc21</smiles>

58b, $69 \%, 92 \%$ ee<smiles>C=CC1OCCc2c(F)cccc21</smiles>

$58 \mathrm{~d}, 64 \%, 92 \%$ ee<smiles>C=CC1OCCc2cc(Br)ccc21</smiles>

$58 \mathrm{e}, 76 \%, 93 \%$ ee<smiles>C=CC1OCCc2ccc(F)cc21</smiles>

58f, $61 \%, 91 \%$ ee

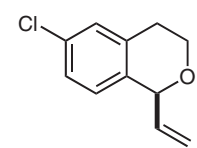

$\mathbf{5 8 g}, 55 \%, 92 \%$ ee

Scheme 20 Synthesis of enantioenriched isochromans via intramolecular allylic $\mathrm{C}-\mathrm{H}$ oxidation

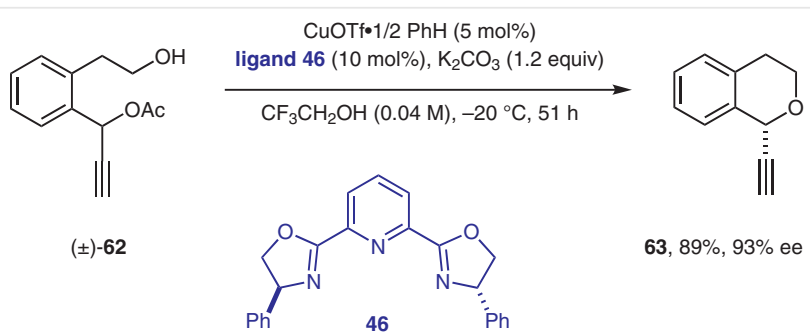<smiles>C#CC1OCCc2cc(C)ccc21</smiles>

63b, $90 \%, 91 \%$ ee<smiles>C#CC1OCCc2ccc(F)cc21</smiles>

$63 e, 90 \%, 87 \%$ ee<smiles>C#C[C@H]1OCCc2ccc(C)cc21</smiles>

63c, $75 \%, 88 \%$ ee<smiles>C#CC1OCCc2ccc(OC)cc21</smiles>

$63 f, 72 \%, 93 \%$ ee

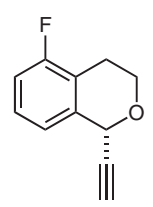

63d, $65 \%, 89 \%$ ee

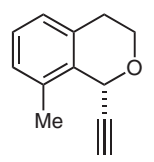

63g, $75 \%, 80 \%$ ee

Scheme 21 Synthesis of enantioenriched isochromans via intramolecular etherification of propargylic esters

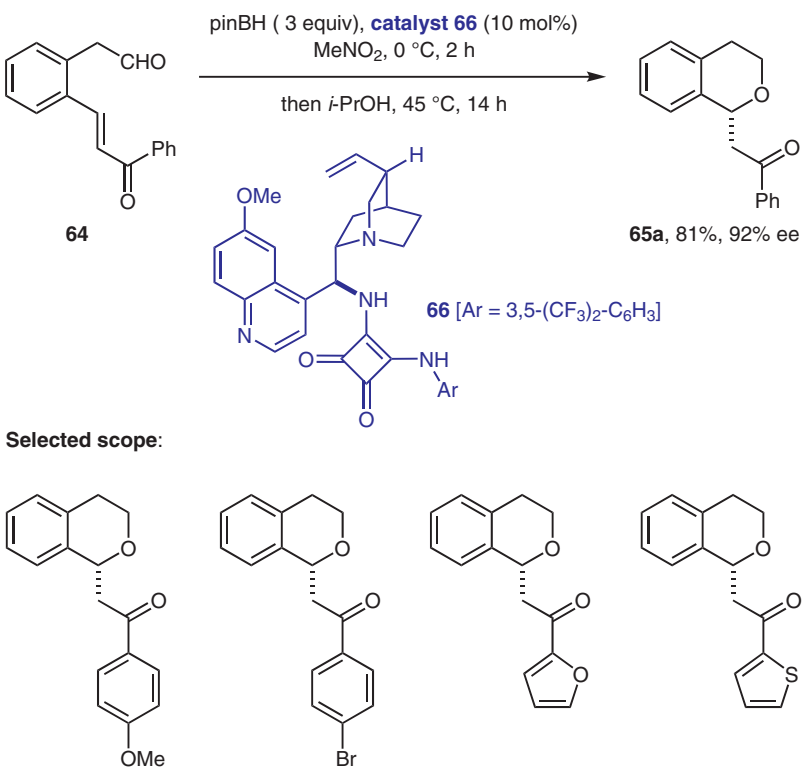

$65 b, 68 \%, 89 \%$ ee $\quad 65 c, 80 \%, 96 \%$ ee $\quad 65 d, 81 \%, 96 \%$ ee $\quad 65 e, 68 \%, 94 \%$ ee<smiles>O=C(C[C@@H]1OCCc2cc3c(cc21)OCO3)c1ccco1</smiles>

$65 \mathbf{g}, 72 \%, 93 \%$ ee<smiles>Cc1ccc2c(c1)C(CC(=O)c1ccco1)OCC2</smiles>

$65 \mathrm{~h}, 82 \%, 94 \%$ ee

$65 f, 70 \%, 93 \%$

Scheme 22 Synthesis of enantioenriched isochromans via intramolecular conjugate addition

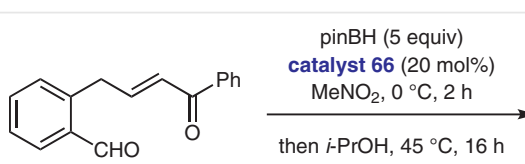

67

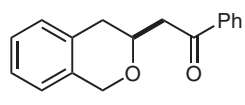

$68,56 \%, 81 \%$ ee

Scheme 23 Synthesis of enantioenriched 3-substituted isochromans via intramolecular conjugate addition

Another rare example of a catalytic enantioselective process leading to isochromans containing a substituent in the 3-position was reported in 2009 (Scheme 24). ${ }^{47}$ As part of a broader effort directed at preparing a range of structurally diverse compounds, Chung and Fu achieved the catalytic enantioselective synthesis of isochroman $\mathbf{7 0}$ from $\alpha, \beta$ alkynyl ester $\mathbf{6 9}$. This isomerization reaction is catalyzed by chiral phosphine 71, operating in concert with benzoic acid. 
<smiles>O=CC#CCCc1ccccc1CO</smiles>

69

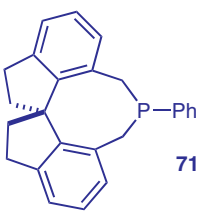

Scheme 24 Synthesis of enantioenriched 3-substituted isochromans via phosphine-catalyzed isomerization of $\alpha, \beta$-alkynyl esters

Examples of catalytic enantioselective reactions that provide enantioenriched tetrahydropyrano[3,4- $b]$ indoles containing substituents in other than the 1-position are shown in Scheme 25 and Scheme 26. In 2011, the You group achieved enantioselective intramolecular FriedelCrafts alkylation reactions of indolyl enones (e.g., 72), providing products such as $\mathbf{7 3}$ with exceptional efficiency (Scheme 25). ${ }^{48}$ Reactions are catalyzed by chiral $N$-triflyl phosphoramide $\mathbf{7 4}$, a catalyst that is remarkably active at $-70{ }^{\circ} \mathrm{C}$. In earlier work published in 2009 , the same group showed that products such as $\mathbf{7 3}$ can be obtained by olefin cross-metathesis/Friedel-Crafts alkylation cascades using a compatible combination of a Ru catalyst and a chiral phosphoric acid catalyst (not shown). ${ }^{49}$<smiles>CCCc1cc2ccc(Br)cc2n1[Na]</smiles>

72

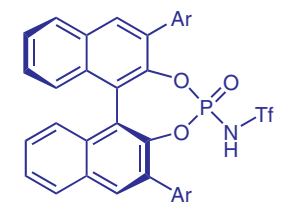

$74(\mathrm{Ar}=9$-anthryl)

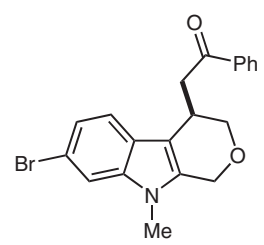

73, $99 \%, 98 \%$ ee
Scheme 25 Synthesis of enantioenriched tetrahydropyrano[3,4-b]indoles by intramolecular Friedel-Crafts alkylation

Highly enantioenriched tetrahydropyrano[3,4- $b$ ]indoles containing a fused ring and two stereogenic centers (e.g., 76) can be prepared from substrates such as 75, as reported by Lu and co-workers in 2017.50 This transformation involves a Pd(II)-catalyzed aminopalladation/1,4-addition sequence that is facilitated by chiral bipyridine ligand $\mathbf{7 7}$.

As is clear from the transformations discussed in this Short Review, access to highly enantioenriched isochromans and tetrahydropyrano[3,4- $b]$ indoles by means of

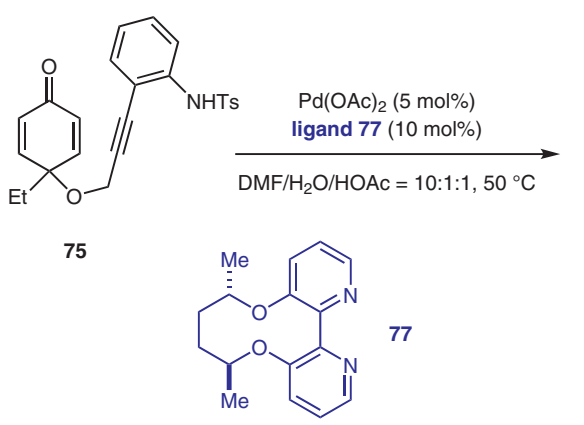

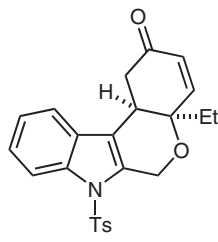

76, $90 \%, 95 \%$ ee
Scheme 26 Synthesis of enantioenriched tetrahydropyrano[3,4-b]indoles by a Pd-catalyzed cascade reaction

asymmetric catalysis has improved dramatically over the past 10 years, with most advances having emerged only in the past 5 years. It is also clear that significant challenges remain. Although highly desirable, for instance for a more efficient synthesis of drug molecules such as etodolac, methods that efficiently install tetrasubstituted stereogenic centers remain rare and have largely been limited to additions to cyclic oxocarbenium ions (Scheme 14). Thus far, there is only one example with low enantioselectivity in which a tetrasubstituted stereogenic center was generated via an oxa-Pictet-Spengler cyclization (Scheme 7). PictetSpengler cyclizations of tryptophols or $\beta$-arylethanols with ketones or ketone surrogates would provide the most direct access to isochromans and tetrahydropyrano[3,4- $b$ ] indoles containing a tetrasubstituted stereogenic center in the 1position. While such reactions are well known in a racemic sense, catalytic enantioselective variants have remained elusive. In addition, highly enantioselective oxa-PictetSpengler reactions of tryptophols have not yet been accomplished with aliphatic aldehydes, and reactions with $\beta$ phenylethanols require the presence of a hydroxyl group in a specific position of the aryl ring. All three of the highly enantioselective oxa-Pictet-Spengler reactions reported to date (Scheme 8, Scheme 9, and Scheme 11) require the presence of hydrogen-bonding donor or acceptor sites on the alcohol substrate. However, encouraging findings such as those summarized in Scheme 6 suggest that such reactions could potentially be rendered highly enantioselective in the absence of obvious directing groups. Overall, there is cause for optimism that many of these limitations will be addressed in the not-too-distant future. We look forward to learning about new advances and hope that this Short Review will motivate others to tackle the remaining challenges.

\section{Funding Information}

This material is based upon work supported by the National Science Foundation under grant CHE-1856613. 


\section{References and Notes}

(1) Zhou, Y. B.; Wang, J.-H.; Li, X. M.; Fu, X. C.; Yan, Z.; Zeng, Y. M.; Li, X. J. Asian Nat. Prod. Res. 2008, 10, 827.

(2) (a) Trisuwan, K.; Rukachaisirikul, V.; Sukpondma, Y.; Phongpaichit, S.; Preedanon, S.; Sakayaroj, J. Tetrahedron 2010, 66, 4484. (b) Kuramochi, K.; Tsubaki, K.; Kuriyama, I.; Mizushina, Y.; Yoshida, H.; Takeuchi, T.; Kamisuki, S.; Sugawara, F.; Kobayashi, S. J. Nat. Prod. 2013, 76, 1737.

(3) Yan, Y.-M.; Dai, H.-Q.; Du, Y.; Schneider, B.; Guo, H.; Li, D.-P.; Zhang, L.-X.; Fu, H.; Dong, X.-P.; Cheng, Y.-X. Bioorg. Med. Chem. Lett. 2012, 22, 4179.

(4) Zhang, L.; Zhu, X.; Zhao, B.; Zhao, J.; Zhang, Y.; Zhang, S.; Miao, J. Vasc. Pharmacol. 2008, 48, 63.

(5) Ennis, M. D.; Ghazal, N. B.; Hoffman, R. L.; Smith, M. W.; Schlachter, S. K.; Lawson, C. F.; Im, W. B.; Pregenzer, J. F.; Svensson, K. A.; Lewis, R. A.; Hall, E. D.; Sutter, D. M.; Harris, L. T.; McCall, R. B. J. Med. Chem. 1998, 41, 2180.

(6) (a) Demerson, C. A.; Humber, L. G.; Philipp, A. H.; Martel, R. R. J. Med. Chem. 1976, 19, 391. (b) Brenna, E.; Fuganti, C.; Fuganti, D.; Grasselli, P.; Malpezzi, L.; Pedrocchi-Fantoni, G. Tetrahedron 1997, 53, 17769.

(7) Katz, A. H.; Demerson, C. A.; Shaw, C. C.; Asselin, A. A.; Humber, L. G.; Conway, K. M.; Gavin, G.; Guinosso, C.; Jensen, N. P. J. Med. Chem. 1988, 31, 1244.

(8) Howe, A. Y. M.; Bloom, J.; Baldick, C. J.; Benetatos, C. A.; Cheng, H.; Christensen, J. S.; Chunduru, S. K.; Coburn, G. A.; Feld, B.; Gopalsamy, A.; Gorczyca, W. P.; Herrmann, S.; Johann, S.; Jiang, X.; Kimberland, M. L.; Krisnamurthy, G.; Olson, M.; Orlowski, M.; Swanberg, S.; Thompson, I.; Thorn, M.; Del Vecchio, A.; Young, D. C.; van Zeijl, M.; Ellingboe, J. W.; Upeslacis, J.; Collett, M.; Mansour, T. S.; O'Connell, J. F. Antimicrob. Agents Chemother. 2004, 48, 4813.

(9) For reviews on the oxa-Pictet-Spengler reaction, see: (a) Larghi, E. L.; Kaufman, T. S. Synthesis 2006, 187. (b) Larghi, E. L.; Kaufman, T. S. Eur. J. Org. Chem. 2011, 5195. (c) Moyano, A.; Rios, R. Chem. Rev. 2011, 111, 4703.

(10) For a very brief summary of this topic (in Japanese), see: Kawato, Y. J. Synth. Org. Chem. Jpn. 2017, 75, 673.

(11) Pictet, A.; Spengler, T. Ber. Dtsch. Chem. Ges. 1911, 44, 2030.

(12) Selected reviews on the Pictet-Spengler reaction: (a) Cox, E. D.; Cook, J. M. Chem. Rev. 1995, 95, 1797. (b) Youn, S. W. Org. Prep. Proced. Int. 2006, 38, 505. (c) Lorenz, M.; Van Linn, M. L.; Cook, J. M. Curr. Org. Synth. 2010, 7, 189. (d) Stockigt, J.; Antonchick, A. P.; Wu, F. R.; Waldmann, H. Angew. Chem. Int. Ed. 2011, 50, 8538. (e) Glinsky-Olivier, N.; Guinchard, X. Synthesis 2017, 49, 2605. (f) Rao, R. N.; Maiti, B.; Chanda, K. ACS Comb. Sci. 2017, 19, 199.

(13) (a) Buschmann, H.; Michel, R. German Patent 614461, 1935. (b) Buschmann, H.; Michel, R. German Patent 617646, 1935.

(14) Wünsch, B.; Zott, M. Liebigs Ann. Chem. 1992, 39.

(15) For an early review on the chemistry of isochromans, see: Markaryan, E. A.; Samodurova, A. G. Russ. Chem. Rev. 1989, 58, 479.

(16) Zeng, M.; You, S.-L. Synlett 2010, 1289.

(17) Liu, L.; Kaib, P. S. J.; Tap, A.; List, B. J. Am. Chem. Soc. 2016, 138, 10822.

(18) Costa, P. R. R.; Cabral, L. M.; Alencar, K. G.; Schmidt, L. L.; Vasconcellos, M. L. A. A. Tetrahedron Lett. 1997, 38, 7021.

(19) For a review on tryptophol and its derivatives, see: Palmieri, A.; Petrini, M. Nat. Prod. Rep. 2019, 36, 490.

(20) Fernandes, R. A.; Brückner, R. Synlett 2005, 1281.

(21) Eey, S. T.-C.; Lear, M. J. Chem. Eur. J. 2014, 20, 11556.
(22) Wang, P.; Zhao, J.-Z.; Li, H.-F.; Liang, X.-M.; Zhang, Y.-L.; Da, C.-S. Tetrahedron Lett. 2017, 58, 129.

(23) Doyle, A. G. Ph.D. Thesis; Harvard University: Cambridge, 2008.

(24) Selected reviews on hydrogen bonding catalysis: (a) Schreiner, P. R. Chem. Soc. Rev. 2003, 32, 289. (b) Takemoto, Y. Org. Biomol. Chem. 2005, 3, 4299. (c) Taylor, M. S.; Jacobsen, E. N. Angew. Chem. Int. Ed. 2006, 45, 1520. (d) Connon, S. J. Chem. Eur. J. 2006, 12, 5418. (e) Doyle, A. G.; Jacobsen, E. N. Chem. Rev. 2007, 107, 5713. (f) Yu, X.; Wang, W. Chem. Asian J. 2008, 3, 516. (g) Hydrogen Bonding in Organic Synthesis; Pihko, P. M., Ed.; Wiley-VCH: Weinheim, 2009. (h) Schenker, S.; Zamfir, A.; Freund, M.; Tsogoeva, S. B. Eur. J. Org. Chem. 2011, 2209. (i) Auvil, T. J.; Schafer, A. G.; Mattson, A. E. Eur. J. Org. Chem. 2014, 2633. (j) Žabka, M.; Šebesta, R. Molecules 2015, 20, 15500. (k) Nishikawa, Y. Tetrahedron Lett. 2018, 59, 216. (1) Reep, C.; Sun, S.; Takenaka, N. Asian J. Org. Chem. 2019, 8, 1306.

(25) Selected reviews on asymmetric anion-binding catalysis: (a) Zhang, Z.; Schreiner, P. R. Chem. Soc. Rev. 2009, 38, 1187. (b) Mahlau, M.; List, B. Angew. Chem. Int. Ed. 2013, 52, 518. (c) Brak, K.; Jacobsen, E. N. Angew. Chem. Int. Ed. 2013, 52, 534. (d) Seidel, D. Synlett 2014, 25, 783. (e) Busschaert, N.; Caltagirone, C.; Van Rossom, W.; Gale, P. A. Chem. Rev. 2015, 115, 8038. (f) Attard, J. W.; Osawa, K.; Guan, Y.; Hatt, J.; Kondo, S.-i.; Mattson, A. Synthesis 2019, 51, 2107.

(26) Lombardo, V. M.; Thomas, C. D.; Scheidt, K. A. Angew. Chem. Int. Ed. 2013, 52, 12910.

(27) Selected reviews on asymmetric Brønsted acid catalysis: (a) Yamamoto, H.; Futatsugi, K. Angew. Chem. Int. Ed. 2005, 44, 1924. (b) Akiyama, T. Chem. Rev. 2007, 107, 5744. (c) Terada, M. Synthesis 2010, 1929. (d) Rueping, M.; Nachtsheim, B. J.; Ieawsuwan, W.; Atodiresei, I. Angew. Chem. Int. Ed. 2011, 50, 6706. (e) Yu, J.; Shi, F.; Gong, L. Z. Acc. Chem. Res. 2011, 44, 1156. (f) Parmar, D.; Sugiono, E.; Raja, S.; Rueping, M. Chem. Rev. 2014, 114, 9047. (g) Akiyama, T.; Mori, K. Chem. Rev. 2015, 115, 9277. (h) Rueping, M.; Parmar, D.; Sugiono, E. Asymmetric Brønsted Acid Catalysis; Wiley-VCH: Weinheim, 2015. (i) Mitra, R.; Niemeyer, J. ChemCatChem 2018, 10, 1221. (j) Sedgwick, D. M.; Grayson, M. N.; Fustero, S.; Barrio, P. Synthesis 2018, 50, 1935.

(28) Ascic, E.; Ohm, R. G.; Petersen, R.; Hansen, M. R.; Hansen, C. L.; Madsen, D.; Tanner, D.; Nielsen, T. E. Chem. Eur. J. 2014, 20, 3297.

(29) Zhao, C.; Chen, S. B.; Seidel, D. J. Am. Chem. Soc. 2016, 138, 9053.

(30) For reviews on iminium catalysis, see: (a) Erkkilae, A.; Majander, I.; Pihko, P. M. Chem. Rev. 2007, 107, 5416. (b) Brazier, J. B.; Tomkinson, N. C. O. In Asymmetric Organocatalysis; List, B., Ed.; Springer: Berlin, 2010, 281.

(31) Das, S.; Liu, L.; Zheng, Y.; Alachraf, M. W.; Thiel, W.; De C, K.; List, B. J. Am. Chem. Soc. 2016, 138, 9429.

(32) Maskeri, M. A.; O'Connor, M. J.; Jaworski, A. A.; Davies, A. V.; Scheidt, K. A. Angew. Chem. Int. Ed. 2018, 57, 17225.

(33) Reisman, S. E.; Doyle, A. G.; Jacobsen, E. N. J. Am. Chem. Soc. 2008, 130, 7198.

(34) For the first report describing catalytic enantioselective additions to oxocarbenium ions, see: Braun, M.; Kotter, W. Angew. Chem. Int. Ed. 2004, 43, 514.

(35) (a) Maity, P.; Srinivas, H. D.; Watson, M. P. J. Am. Chem. Soc. 2011, 133, 17142. (b) Watson, M. P.; Maity, P. Synlett 2012, 23 , 1705.

(36) Dasgupta, S.; Rivas, T.; Watson, M. P. Angew. Chem. Int. Ed. 2015 , $54,14154$.

(37) Meng, Z.; Sun, S.; Yuan, H.; Lou, H.; Liu, L. Angew. Chem. Int. Ed. 2014, 53, 543. 
(38) While not catalytic, enantioselective modification of parent isochroman had previously been achieved by deprotonation with $t$-BuLi in the presence of superstoichiometric amounts of a chiral ligand, followed by treatment with various electrophiles, see: Tomooka, K.; Wang, L.-F.; Okazaki, F.; Nakai, T. Tetrahedron Lett. 2000, 41, 6121.

(39) Catalytic enantioselective additions of boronic acids to structurally related chrome acetals are significantly more developed. See, for example: Moquist, P. N.; Kodama, T.; Schaus, S. E. Angew. Chem. Int. Ed. 2010, 49, 7096.

(40) Wan, M.; Sun, S.; Li, Y.; Liu, L. Angew. Chem. Int. Ed. 2017, 56, 5116.

(41) Li, Y.; Wan, M.; Sun, S.; Fu, Z.; Huang, H.; Liu, L. Org. Chem. Front. 2018, 5, 1280.

(42) Lu, R.; Li, Y.; Zhao, J.; Li, J.; Wang, S.; Liu, L. Chem. Commun. 2018, 54, 4445 .
(43) (a) Miyata, K.; Kutsuna, H.; Kawakami, S.; Kitamura, M. Angew. Chem. Int. Ed. 2011, 50, 4649. (b) Miyata, K.; Kitamura, M. Synthesis 2012, 44, 2138.

(44) Ammann, S. E.; Liu, W.; White, M. C. Angew. Chem. Int. Ed. 2016, $55,9571$.

(45) Liu, S.; Nakajima, K.; Nishibayashi, Y. RSC Adv. 2019, 9, 18918.

(46) Ravindra, B.; Maity, S.; Das, B. G.; Ghorai, P. J. Org. Chem. 2015, 80,7008 .

(47) Chung, Y. K.; Fu, G. C. Angew. Chem. Int. Ed. 2009, 48, 2225.

(48) Zhang, J.-W.; Cai, Q.; Shi, X.-X.; Zhang, W.; You, S.-L. Synlett 2011, 1239.

(49) Cai, Q.; Zhao, Z.-A.; You, S.-L. Angew. Chem. Int. Ed. 2009, 48, 7428.

(50) Chen, J.; Han, X.; Lu, X. Angew. Chem. Int. Ed. 2017, 56, 14698. 